\title{
Ecogenetics of Triatoma sordida and Triatoma guasayana (Hemiptera: Reduviidae) in the Bolivian Chaco
}

\author{
François Noireau/ ${ }^{+}$, Teresa Gutierrez*, Rosmary Flores**, Frédérique \\ Brenière***, Marie France Bosseno $^{* * *}$, Cristina Wisnivesky-Colli****
}

\begin{abstract}
Institut de Recherche pour le Développement, Casilla Postal 9214, La Paz, Bolivia *Museo de Historia Natural Noel Kempff M., Casilla Postal 2489, Santa Cruz, Bolivia **Instituto Boliviano de Biología de Altura, Casilla Postal 641, La Paz, Bolivia ***UMR CNRS/IRD, BP 5045, 34032 Montpellier Cedex, France ****Unidad Ecología de Reservorios y Vectores de Parásitos, Departamento de Ciencias Biológicas, Universidad de Buenos Aires, 1428 Buenos Aires, Argentina
\end{abstract}

Triatoma guasayana and two putative cryptic species pertaining to T. sordida complex (named groups 1 and 2) occur in sympatry in the Bolivian Chaco. Using multilocus enzyme electrophoresis and subsequent genetic analysis, our work assesses their population distribution and dispersal capacity in domestic, peridomestic, and silvatic environments. Our collections by light trap in the silvatic environment indicated a predominance of $\mathrm{T}$. guasayana and $\mathrm{T}$. sordida group 2 and a lesser abundance of $\mathrm{T}$. sordida group 1 ( $\leq$ $10 \%$ of the total of captures). Their similar distribution in two silvatic areas $80 \mathrm{~km}$ apart supports the hypothesis of their homogeneous dispersal through the Bolivian Chaco. The distribution of $\mathrm{T}$. guasayana and $\mathrm{T}$. sordida groups 1 and 2 was similar between silvatic environment and peridomestic ecotopes where $25 \%$ of positive places was occupied by two or three species. Bromeliads were confirmed as favorable shelter for $\mathrm{T}$. guasayana but were free of $\mathrm{T}$. sordida. T. sordida group 1 and to a lesser extent $\mathrm{T}$. guasayana would be more invasive vectors for houses than $\mathrm{T}$. sordida group 2 . The spatial partition in the three species sampled in two distant sites suggested a reduced dispersive capacity.

Key words: Triatoma sordida - Triatoma guasayana - distribution - population genetics - multilocus enzyme electrophoresis - Bolivia

Triatoma sordida Stal and T. guasayana Wygodzinsky and Abalos are silvatic triatomine species known from a wide variety of natural ecotopes. They are also particularly prevalent in peridomestic habitats and have been increasingly reported from houses (Forattini 1980, Diotiaiuti et al. 1993, Wisnivesky-Colli et al. 1993, Noireau et al. 1996). The two species are considered closely related because they are morphologically very similar, their distribution overlaps throughout northern Argentina and parts of the Chaco region in Bolivia and Paraguay, they occupy a comparable variety of ecotopes and interspecific crossings can occur experimentally (Usinger et al. 1966, Pietrokovsky et al. 1994, Schofield 1994). The analysis of available epidemiological data suggests

\footnotetext{
This study received financial support from the UNDP/ World Bank/WHO Special Program for Research and Training in Tropical Disease (grant 940209) and the French Ministry of Foreign Affairs.

${ }^{+}$Corresponding author. Fax:+55-21-290.9339. E-mail: noireauf@ceibo.entelnet.bo

Received 25 August 1998

Accepted 22 February 1999
}

that they could play a significant role in the transmission of Trypanosoma cruzi, the agent of Chagas disease, particularly after the eradication of $T$. infestans from the domestic environment (Dias 1988, Schofield 1994).

Recent studies have shown that the vectorial significance of T. sordida would be considerably less than previously thought (Noireau et al. 1997). Nevertheless, the ability of $T$. sordida and $T$. guasayana to colonize artificial ecotopes and their wide distribution lead to keep attentive (Schofield 1994, Gajate et al. 1996).

Multilocus enzyme electrophoresis (MLEE) is a powerful tool to distinguish among sympatric related species (Thorpe \& Solé-Cava 1994), as it is the case of T. sordida and T. guasayana whose immature stages are hard to discriminate (Garcia et al. 1995, Noireau et al. 1998). Recently, genetic studies have shown a high level of differentiation between T. sordida populations that might be compatible with the hypothesis of two biological species (Panzera et al. 1997, Noireau et al. 1998). In the Bolivian Chaco, our study area, the sympatric occurring of $T$. guasayana and two $T$. sordida separate populations (named groups 1 and 2) was demonstrated by Noireau et al. (1998). Because these T. sordida groups could exhibit distinct behavior 
and vectorial capacity, additional studies should take their distinct population subdivision into consideration.

Considering that the eradication of $T$. infestans would provide a unique epidemiological opportunity for secondary species, we combined ecological observations on $T$. guasayana and T. sordida in the Bolivian Chaco with MLEE and genetic analysis in order to assess their population distribution and dispersal capacity in domestic, peridomestic, and silvatic environments.

\section{MATERIALS AND METHODS}

Study areas - The field work was carried out in the phytogeographic region of the Chaco, in the southern part of the Department of Santa Cruz, Bolivia. The main environmental characteristics of this semi-arid region are: (i) $300-600 \mathrm{~m}$ altitude, (ii) a mean temperature of $26^{\circ} \mathrm{C}$, (iii) an average annual rainfall of about $600 \mathrm{~mm}$ and (iiii) a marked seasonality, with a dry season from March to October and a wet season the rest of the year. The first surveyed area was La Choza (18034'516"S; $62^{\circ} 40^{\prime} 108^{\prime \prime} \mathrm{W}$ ), an isolated site located on the way to Izozog. The area is covered by a dense and thick vegetation (elevation 4-6 m) of hardwood trees dominated by Ruprechtia triflora with emerging trees up to $12 \mathrm{~m}$ high (Aspidosperma quebrachoblanco, Chorisia insignis...). In the lowest stratum thorn shrubs, bromeliads and cacti predominate. The second study area, Izozog and its surrounding forest (19³0'509' S; 62 33'639' W), is located 80 $\mathrm{km}$ south from La Choza and inhabited by the stable Chiriguano Izozo ethnic group. Dwellings are mainly of wattle and daub construction and roofed with straw. The peridomestic structures located 5$10 \mathrm{~m}$ from houses are mainly kitchens: a rudimentary furnished premise consisting of mud-oven surrounded by a branch pen. The absence of clearly defined peridomestic structures for domestic animals is typical of this area. In particular, there is a virtual-absence of chicken coops with chickens roosting in trees at night. The density of bromeliads (Bromelia serra and, to a lesser extent, $B$. hieronymi) was assessed in the peridomestic area since they are abundant around houses and were already identified as wild biotopes of $T$. guasayana in the Argentinean Chaco (Wisnivesky-Colli et al. 1997). Twenty-five squares ( $2 \times 2 \mathrm{~m}$ ) were randomly distributed on the left and right side of a $100 \mathrm{~m}$ long transect. All bromeliads located inside each square were counted. The forest surrounding Izozog is similar as that above mentioned but cacti, bromeliads and shrubs are more scattered and the canopy is lower (8 $\mathrm{m}$ for emerging trees).

Collection of triatomines - With regard to $T$. infestans, the main domiciliated vector in this re- gion, a previous entomological survey performed at Izozog showed that $86 \%$ of houses were infested. The current study was focused on secondary triatomine species, mainly $T$. sordida and $T$. guasayana. Insects were collected in natural environment, peridomestic areas, and domestic structures from August 1994 to October 1996. During the dry season, light collections were performed at the site of La Choza and in the forest surrounding the locality of Izozog. The light system consisted of a vertical white cloth simultaneously illuminated by a $12-\mathrm{V}$ fluorescent black light tube and a 150 V mercury vapor light. The light trap was operated for four nights at La Choza and two at Izozog. Artificial peridomestic structures, principally kitchens, were investigated at Izozog. Triatomine bugs were collected from furniture and waste clothing left on the branch pen. Bromeliads located in the vicinity of houses at Izozog and the close silvatic environment were searched for the presence of triatomines. Lastly, a collection of triatomines $(0.5$ $\mathrm{man} / \mathrm{hr}$ ) was carried out in 42 houses of Izozog.

Processing of insects - The collected insects were placed in plastic bottles containing filter paper and transported to the laboratory. The morphological separation of adults was performed according to Lent and Wygodzinsky (1979). Samples were examined for flagellates by direct microscopic observation of feces droplets at 400x magnification. In addition feces aliquots obtained from most of the positive insects were stored at $-20^{\circ} \mathrm{C}$ for subsequent confirmation of $T$. cruzi infection by polymerase chain reaction (PCR) amplification, according to Brenière et al. (1995).

Isoenzyme electrophoresis - Electrophoretic analyses were performed in order to discriminate among nymphal instars and adults of $T$. sordida groups 1,2, and T. guasayana as well as for population genetics studies. All insects alive on arrival to the laboratory were processed. The technique was performed on cellulose acetate plates (Helena Laboratories, Beaumont, TX). Thoracic muscle was dissected from each insect and processed for electrophoresis as described by Noireau et al. (1998). The following seven enzyme systems were assayed: aspartate aminotransferase (EC 2.6.1., GOT); glucose-phosphate isomerase (EC 5.3.1.9., GPI); isocitrate dehydrogenase (EC 1.1.1.42., IDH); leucine aminopeptidase (EC 3.4.11.1., LAP); malate dehydrogenase (EC 1.1.1.37., MDH); malic enzyme (EC 1.1.1.40., ME); and phosphoglucomutase (EC 2.7.5.1., PGM). The zymograms corresponding to seven loci (Got, Gpi, Idh1, Idh2, Lap2, Me 1, and Pgm) provided a reliable identification of T. sordida and T. guasayana. Also fixed genetic differences at $I d h 2$ and $M d h 2$ loci were used for distinguishing $T$. sordida groups 1 and 2 
(Noireau et al. 1998). Although T. sordida group 2 has not still received formal nomenclatural recognition as a new species, it will be considered as putative species in this work.

Data analysis - Genetic and spatial structure of triatomine populations and subpopulations was investigated. Genetic interpretation was based on previous description of $T$. sordida and $T$. guasayana variability (Noireau et al. 1998). For the analysis of spatial subdivision of populations, only two possible alleles were taken into account: the most frequent one, and all other ones plotted together as a unique allele. Analysis was performed in triatomines issued from areas of Izozog (silvatic and domestic/peridomestic populations) and $\mathrm{La}$ Choza (silvatic populations), using Nei's F statistics analysis (Nei 1987). Fit and Fis measure the departure from panmixia of individuals relative to the total population and its subpopulations, respectively. Fst measures the gene frequencies differences among subpopulations.

\section{RESULTS}

Distribution of Triatominae - The distribution of species, according to collecting site and ecotope, and characterized by electrophoretic analysis is presented in Table I. The survey of 42 houses at Izozog showed that $T$. sordida and T. guasayana were uncommonly found indoors. Only seven $T$. sordida (four scored for the group 1 and three for the group 2) and six T. guasayana adults were collected. At Izozog, 48 peridomestic artificial ecotopes positive for triatomines, mostly waste clothing, were studied. According to their relative abundance, $T$. sordida group 2 prevailed over $T$. guasayana and T. sordida group 1 (55.4\%, 37\% and $7.6 \%$ of total capture, respectively). Thirtysix positive ecotopes were occupied by a single species $(75 \%)$ when 12 contained two or three species $(25 \%)$. T. sordida group 2 occupied $62.5 \%$ of positive ecotopes followed by $T$. guasayana (54.2\%) and T. sordida group 1 (12.5\%). One hundred and thirty-nine bromeliads (Bromelia serra and $B$. hieronymi) located in the vicinity of houses were dissected and $12(8.6 \%)$ were positive for triatomines (19 nymphal instars and two adults collected). The genetic characterization of insects demonstrated that all positive plants were infested by $T$. guasayana. The bromeliad density was $9.9 \pm$ 4.5 plants $/ 4 \mathrm{~m}^{2}$ when $96 \%$ of units surveyed had $\geq$ 1 plant; the average number of triatomines per positive bromeliad was 1.7. The 49 plants investigated

TABLE I

Distribution of Triatoma species according to collecting area and ecotope

\begin{tabular}{|c|c|c|c|c|c|}
\hline $\begin{array}{l}\text { Collecting } \\
\text { area }\end{array}$ & Ecotope & Species & $\begin{array}{c}\text { No. of nymphs } \\
\text { captured }(\%)\end{array}$ & $\begin{array}{l}\text { No. of adults } \\
\text { captured }(\%)\end{array}$ & $\begin{array}{c}\text { Total of triatomines } \\
\text { captured }(\%)\end{array}$ \\
\hline & $\begin{array}{l}\text { Light traps in } \\
\text { natural } \\
\text { environment }\end{array}$ & $\begin{array}{l}\text { T. sordida group } 1 \\
\text { T. sordida group } 2 \\
\text { T. guasayana } \\
\text { Total }\end{array}$ & $\begin{array}{l}0 \\
0 \\
0 \\
0\end{array}$ & $\begin{array}{c}3(7.2) \\
29(69.0) \\
10(23.8) \\
42\end{array}$ & $\begin{array}{c}3(7.2) \\
29(69.0) \\
10(23.8) \\
42\end{array}$ \\
\hline & $\begin{array}{l}\text { Peridomestic } \\
\text { artificial } \\
\text { structures }\end{array}$ & $\begin{array}{l}\text { T. sordida group } 1 \\
\text { T. sordida group } 2 \\
\text { T. guasayana } \\
\text { Total }\end{array}$ & $\begin{array}{c}2(5.6) \\
24(66.7) \\
10(27.7) \\
36\end{array}$ & $\begin{array}{l}7(8.4) \\
42(50.6) \\
34(41.0) \\
83\end{array}$ & $\begin{array}{c}9(7.6) \\
66(55.4) \\
44(37.0) \\
119\end{array}$ \\
\hline & $\begin{array}{l}\text { Peridomestic } \\
\text { bromeliads }\end{array}$ & $\begin{array}{l}\text { T. sordida group } 1 \\
\text { T. sordida group } 2 \\
\text { T. guasayana } \\
\text { Total }\end{array}$ & $\begin{array}{l}0 \\
0 \\
19(100) \\
19\end{array}$ & $\begin{array}{l}0 \\
0 \\
2(100) \\
2\end{array}$ & $\begin{array}{l}0 \\
0 \\
21(100) \\
21\end{array}$ \\
\hline & $\begin{array}{l}\text { Domestic } \\
\text { structures }\end{array}$ & $\begin{array}{l}\text { T. sordida group } 1 \\
\text { T. sordida group } 2 \\
\text { T. guasayana } \\
\text { Total }\end{array}$ & $\begin{array}{l}0 \\
0 \\
0 \\
0\end{array}$ & $\begin{array}{l}4(30.8) \\
3(23.1) \\
6(46.1) \\
13\end{array}$ & $\begin{array}{r}4(30.8) \\
3(23.1) \\
6(46.1) \\
13\end{array}$ \\
\hline & $\begin{array}{l}\text { Total of } \\
\text { ecotopes }\end{array}$ & $\begin{array}{l}\text { T. sordida group } 1 \\
\text { T. sordida group } 2 \\
\text { T. guasayana } \\
\text { Total }\end{array}$ & $\begin{array}{c}2(3.6) \\
24(43.6) \\
29(52.8) \\
55\end{array}$ & $\begin{array}{l}14(10.0) \\
74(52.9) \\
52(37.1) \\
140\end{array}$ & $\begin{array}{l}16(8.2) \\
98(50.3) \\
81(41.5) \\
195\end{array}$ \\
\hline La Choza & $\begin{array}{l}\text { Light traps in } \\
\text { natural } \\
\text { environment }\end{array}$ & $\begin{array}{l}\text { T. sordida group } 1 \\
\text { T. sordida group } 2 \\
\text { T. guasayana } \\
\text { Total }\end{array}$ & $\begin{array}{l}0 \\
0 \\
0 \\
0\end{array}$ & $\begin{array}{l}12(10.3) \\
55(47.5) \\
49(42.2 \\
116\end{array}$ & $\begin{array}{l}12(10.3) \\
55(47.5) \\
49(42.2) \\
116\end{array}$ \\
\hline
\end{tabular}


in the silvatic environment were negative. Light collection performed at Izozog showed the following distribution of triatomine species: $T$. sordida group 2 predominated (69\%) followed by $T$. guasayana $(23.8 \%)$ and T. sordida group 1 (7.2\%). With regard to La Choza, light collections showed that $T$. sordida group 2 and T. guasayana $(47.5 \%$ and $42.2 \%$, respectively) prevailed broadly over T. sordida group 1 (10.3\%). The relative distribution of species did not differ significantly between collections performed in both silvatic areas $(P=0.051$, Fisher's exact test). At Izozog, the distribution of species was similar between light collections and peridomestic ecotopes $(P=0.263)$. On the other hand, their distribution showed significant differences between samples from domestic and peridomestic structures $(P=0.015)$ as well as between adults collected in domestic and silvatic environment $(P=0.006)$. The paired comparison of the number of insects of each species collected in light traps and those found in domestic structures showed that $T$. sordida group 1 , and to a lesser extent $T$. guasayana, were relatively more abundant than $T$. sordida group 2 inside houses.

Infection rate of triatomines - Results are summarized in Table II. Adults of the three species dispersing by flight showed similar trypanosome infection rates (data from Izozog and La Choza pooled). In artificial structures, the only significant difference was detected between $T$. guasayana and T. sordida group $2(23.3 \%$ vs $3.8 \% ; P<0.01)$. The three species showed similar infection rates when we compared silvatic and artificial ecotopes. The PCR technique performed on the positive fecal samples confirmed that triatomines were actually infected by $T$. cruzi (visualization of a band at $270 \mathrm{bp}$, Brenière et al. 1995).

Isoenzymatic variability - Of the seven systems tested, three were variable for T. guasayana (GOT, MDH and PGM), two for T. sordida group 1 (MDH and PGM) and three for $T$. sordida group 2 (IDH, MDH and PGM).
Genetic structure and spatial partition of populations - The distribution of genotypes in the three species according to the site of collection is showed in the Table III. Fis test did not detect departure from panmixia of individuals relative to the different subpopulations (Table IV). For the total populations, Fit detected departure from panmixia for T. sordida group 1 (Pgm) and T. guasayana $(M d h l)$. On the other hand, the total population of T. sordida group 2 was in equilibrium at the three analyzed loci. The Fst, which measures the gene frequencies differences among subpopulations, detected spatial partition for the three species at at least one locus.

\section{DISCUSSION}

T. sordida is an epidemiological problem in several countries of the Southern Cone because it has a wide range of silvatic ecotopes but can also form large populations in peridomestic habitats and readily recolonize sprayed houses when residual insecticide activity ends (Garcia-Zapata \& Marsden 1992, Diotaiuti et al. 1993). In several regions of Bolivia, the infestation of houses by $T$. sordida may be considered as primary, i.e. not consequent upon the eradication of $T$. infestans (Noireau et al. 1995, 1996). Regarding T. guasayana, it presents a similar adaptation to artificial habitat in a more reduced area. In the Argentinean Chaco at Santiago del Estero, it colonizes bromeliads (four species including $B$. serra), cacti, $\log$ s and tree cavities (Wisnivesky-Colli et al. 1997). Colonies are also found in the peridomicile, specially in branch pens which include cacti and bromeliads in their structure, where this triatomine feeds on domestic animals (Gajate et al. 1996). In that area, T. guasayana invades houses and domestic collections contain dispersive females that fed on humans (Wisnivesky-Colli et al. 1993).

As demonstrated by Noireau et al. (1998), the Bolivian Chaco is characterized by the occurrence in sympatry of two cryptic species pertaining to $T$.

TABLE II

Trypanosoma cruzi infection rate according to the species and ecotope

\begin{tabular}{llcc}
\hline Ecotope & Species & No. examined & No. positive (\%) \\
\hline \multirow{3}{*}{$\begin{array}{l}\text { Silvatic } \\
\text { environment }\end{array}$} & T. sordida group 1 & 3 & 0 \\
& T. sordida group 2 & 23 & $1(4.3)$ \\
& T. guasayana & 11 & $1(9.1)$ \\
Total & 37 & $2(5.4)$ \\
Peridomestic & T. sordida group 1 & 12 & $2(16.7)$ \\
and domestic & T. sordida group 2 & 52 & $2(3.9)$ \\
ecotopes & T. guasayana & 43 & $10(23.3)$ \\
& Total & 107 & $14(13.1)$ \\
\hline
\end{tabular}


TABLE III

Genotypes in the three species of Triatoma according to the site of collection

\begin{tabular}{|c|c|c|c|c|c|c|c|c|c|c|}
\hline \multirow[t]{2}{*}{ Especie } & \multirow[t]{2}{*}{ Site } & \multicolumn{3}{|c|}{ Pgm } & \multicolumn{3}{|c|}{$M d h 1$} & \multicolumn{3}{|c|}{$I d h 1 / G o t^{a}$} \\
\hline & & $\mathrm{a} / \mathrm{a}$ & $\mathrm{a} / \mathrm{N}$ & $\mathrm{N} / \mathrm{N}$ & $\mathrm{a} / \mathrm{a}$ & $\mathrm{a} / \mathrm{N}$ & $\mathrm{N} / \mathrm{N}$ & $\mathrm{a} / \mathrm{a}$ & $\mathrm{a} / \mathrm{N}$ & $\mathrm{N} / \mathrm{N}$ \\
\hline \multirow{5}{*}{$\begin{array}{l}\text { T. sordida } \\
\text { group } 1\end{array}$} & $\operatorname{Izozog}(\mathrm{S})$ & 2 & 1 & 0 & 2 & 1 & 0 & & & \\
\hline & $\operatorname{Izozog}(\mathrm{PD}+\mathrm{D})$ & 6 & 5 & 2 & 5 & 7 & 1 & & & \\
\hline & Total Izozog & 8 & 6 & 2 & 7 & 8 & 1 & & & \\
\hline & $\operatorname{La} \operatorname{Choza}(\mathrm{S})$ & 12 & 0 & 0 & 3 & 3 & 0 & & & \\
\hline & Izozog + La Choza & 20 & 6 & 2 & 10 & 11 & 1 & & & \\
\hline \multirow{5}{*}{$\begin{array}{l}\text { T. sordida } \\
\text { group } 2\end{array}$} & $\operatorname{Izozog}(\mathrm{S})$ & 26 & 3 & 0 & 20 & 7 & 2 & 3 & 16 & 10 \\
\hline & $\operatorname{Izozog}(\mathrm{PD}+\mathrm{D})$ & 52 & 11 & 3 & 38 & 25 & 2 & 15 & 34 & 15 \\
\hline & Total Izozog & 78 & 14 & 3 & 58 & 32 & 4 & 18 & 50 & 25 \\
\hline & La Choza $(\mathrm{S})$ & 47 & 8 & 0 & 19 & 7 & 0 & 8 & 32 & 14 \\
\hline & Izozog + La Choza & 125 & 22 & 3 & 77 & 39 & 4 & 26 & 82 & 39 \\
\hline \multirow[t]{5}{*}{ T. guasayana } & $\operatorname{Izozog}(\mathrm{S})$ & 10 & 0 & 0 & 5 & 3 & 1 & 5 & 4 & 1 \\
\hline & $\operatorname{Izozog}(\mathrm{PD}+\mathrm{D})$ & 62 & 7 & 0 & 37 & 25 & 3 & 36 & 14 & 6 \\
\hline & Total Izozog & 72 & 7 & 0 & 42 & 28 & 4 & 41 & 18 & 7 \\
\hline & La Choza $(\mathrm{S})$ & 35 & 12 & 1 & 10 & 10 & 7 & 34 & 11 & 2 \\
\hline & Izozog + La Choza & 107 & 19 & 1 & 52 & 38 & 11 & 75 & 29 & 9 \\
\hline
\end{tabular}

a/a: homozygotes for the prevailing allele; a/N: heterozygotes between the prevailing allele and any other one; N/N: homozygotes for alleles other than the prevailing one; S: silvatic environment; PD: peridomestic artificial structures and bromeliads; D: domestic structures; $a$ : Idh1 for T. sordida group 2 and Got for T. guasayana.

TABLE IV

F statistics at polymorphic loci among Triatoma sordida group 1, T. sordida group 2 and T. guasayana from the areas of Izozog (silvatic and peridomestic/domestic populations) and La Choza (silvatic populations)

\begin{tabular}{|c|c|c|c|c|c|c|c|c|c|}
\hline & \multicolumn{3}{|c|}{ Pgm } & \multicolumn{3}{|c|}{$M d h 1$} & \multicolumn{3}{|c|}{ Idh1/Got ${ }^{a}$} \\
\hline & Fis & Fit & Fst & Fis & Fit & Fst & Fis & Fit & Fst \\
\hline T. sordida group 1 & 0.329 & $0.476^{b}$ & $0.200^{c}$ & -0.138 & -0.035 & 0.091 & & & \\
\hline T. sordida group 2 & 0.103 & 0.121 & $0.020^{b}$ & 0.006 & 0.024 & 0.018 & -0.133 & -0.112 & 0.182 \\
\hline T. guasayana & 0.008 & 0.079 & $0.072^{d}$ & 0.153 & $0.280^{d}$ & $0.150^{d}$ & 0.041 & 0.061 & 0.021 \\
\hline
\end{tabular}

a: Idh1 for T. sordida group 2 and Got for T. guasayana; $b: P<0.05 ; c: P<0.01 ; d$ : $P<0.001$.

sordida complex in addition to T. guasayana. The absence of hybrid forms detected by isoenzyme analysis between these species confirms their reproductive isolation in nature (Noireau et al. 1998). Contrary to other regions of Bolivia where $T$. sordida group 1 is domiciliated, any of these species form domestic colonies in the Chaco. The intradomiciliary presence of important colonies of T. infestans probably prevents their process of colonization here, a fact also observed by Gajate et al. (1996) in Santiago del Estero, Argentina. In addition, the three species form numerous colonies in peridomestic ecotopes where they occur frequently in association.

If the relative distribution of triatomine species collected by light trap at Izozog is representative of their abundance in silvatic environment (comparable attraction to light), the three species would present a comparable potential of settlement in peridomestic structures. A study carried out in the Argentin Chaco (Wisnivesky-Colli et al. 1993) considered that $T$. guasayana predominated over T. sordida in light collections and among adults flying into houses, placing T. guasayana as the main potential substitute of $T$. infestans. Nevertheless, the characterization of $T$. sordida population according to the group was not studied at that time. Our results seem to indicate that $T$. sordida group 1 and to a lesser extent $T$. guasayana would be more invasive vectors for houses than $T$. sordida group 2. The similar distribution of the three species collected by light trap at Izozog and La Choza, $80 \mathrm{~km}$ apart, supports the hypothesis of their homogeneous distribution through the Bolivian Chaco. If we consider that the three species have a comparable attraction to light, our collectings indicate a lesser abundance of T. sordida group 1 in the Bolivian Chaco. 
Bromeliads were classically considered as ecotope to T. sordida (Lent \& Wygodzinsky 1979) until Wisnivesky-Colli et al. (1997) found 22\% of bromeliads infested by T. guasayana in Argentina. These plants seem to be favorable shelter, particularly in the vicinity of houses, and the former authors did not find difference between infestation rates of bromeliads located either in the forest or in the peridomicile. The high density of plants and their infestation rate by triatomines in the peridomestic environment of both Bolivian and Argentin Chaco lead us to point out their significance for the vector control of Chagas disease.

T. guasayana, $T$. sordida group 1 , and T. sordida group 2 were found infected by $T$. cruzi in collections made with light trap as well as in artificial structures. The domestic occurrence in the Velasco area of infected T. sordida group 1 does not allow for consideration of this species as efficient vector of $T$. cruzi to humans (Noireau et al. 1997). The vectorial capacity of T. sordida group 2 and T. guasayana is unknown. The high $T$. cruzi infection rate detected in domestic/peridomestic T. guasayana at Izozog supports its potential vector role.

The enzymatic study performed on these three triatomine species confirms the variability of loci previously evidenced (Noireau et al. 1998). Generally, the observed allelic frequencies with MLEE are not influenced by selective factors (Nei 1987). Moreover, current studies of intraspecific crossing would allow to know if genes are really independent. These cautions considered, we can contemplate the existence of spatial partition in the three species detected by the Fit test which suggests their reduced dispersive capacity. In spite of its ability to fly, $T$. sordida group 2 seems to be restricted to the Chaco because the characterization of T. sordida populations from other Bolivian regions and Brazil always indicates their relationship with the group 1 (Noireau et al. 1998). Its limited distribution would be explained by (i) its close dependence to the Chaco ecosystem and/or (ii) a limited passive dispersion. The last hypothesis is strengthened by the fact that $T$. sordida group 1 was only detected in bird-nests of this area (Noireau, unpublished data); the passive transport of nymphs of this species among the feathers of birds, demonstrated by Forattini et al. (1971), would be an explanation to its wider distribution.

\section{ACKNOWLEDGEMENTS}

To JP Dujardin for his contribution to our study and $\mathrm{J}$ Ireland for reviewing the manuscript.

\section{REFERENCES}

Brenière F, Bosseno MF, Telleria J, Carrasco R, Vargas F, Yaksic N, Noireau F 1995. Field application of
PCR diagnosis and strain typing of Trypanosoma cruzi in bolivian triatomines. Am J Trop Med Hyg 53: 179-184.

Dias JCP 1988. Controle de vetores da doença de Chagas no Brasil e risco de reinvasão domiciliar por vetores secundários. Mem Inst Oswaldo Cruz 83: 387-391.

Diotaiuti L, Loiola CF, Falcão PL, Dias JCP 1993. The ecology of Triatoma sordida in natural environments in two different regions of the State of Minas Gerais, Brazil. Rev Inst Med Trop S Paulo 35: 237-245.

Forattini OP 1980. Biogeografia, origem e distribuição da domiciliação de triatomíneos no Brasil. Rev Saú Públ S Paulo 14: 265-299.

Forattini OP, Rocha e Silva EO da, Ferreira OA, Rabello EX, Pattoli DGB 1971. Aspectos ecológicos da tripanossomose americana. III. Dispersão local de triatomíneos, com especial referência ao Triatoma sordida. Rev Saú Públ S Paulo 5: 193-205.

Gajate PP, Bottazi MV, Pietrokovsky SM, WisniveskyColli C 1996. Potential colonization of the peridomicile by Triatoma guasayana (Hemiptera: Reduviidae) in Santiago del Estero, Argentina. JMed Entomol 33: 635-639.

García BA, Canale DM, Blanco A 1995. Genetic structure of four species of Triatoma (Hemiptera: Reduviidae) from Argentina. J Med Entomol 32: 134-137.

Garcia Zapata MTA, Marsden PD 1992. Control of the transmission of Chagas' disease in Mambai, Goiás, Brazil (1980-1988). Am J Trop Med Hyg 46: 440443.

Lent H, Wygodzinsky P 1979. Revision of the Triatominae (Hemiptera, Reduviidae), and their significance as vectors of Chagas disease. Bul Am Mus Nat Hist 163: 125-520.

Nei M 1987. Molecular Evolutionary Genetics, Columbia University Press, New York, 512 pp.

Noireau F, Bosseno MF, Carrasco R, Telleria J, Vargas F, Camacho C, Yaksic N, Brenière F 1995. Sylvatic triatomines (Hemiptera: Reduviidae) in Bolivia. Trends towards domesticity and possible infection with Trypanosoma cruzi (Kinetoplastida: Trypanosomatidae). J Med Entomol 32: 594-598.

Noireau F, Brenière F, Cardozo L, Bosseno MF, Vargas F, Peredo C, Medinacelli M 1996. Current spread of Triatoma infestans at the expense of Triatoma sordida in Bolivia. Mem Inst Oswaldo Cruz 91: 271-272.

Noireau F, Brenière F, Ordoñez J, Cardozo L, Morochi W, Gutierrez T, Bosseno MF, Garcia S, Vargas F, Yaksic N, Dujardin JP, Peredo C, Wisnivesky-Colli C 1997. Low probability of transmission of Trypanosoma cruzi to humans by domiciliary Triatoma sordida in Bolivia. Trans R Soc Trop Med Hyg 91: 653-656.

Noireau F, Gutierrez T, Zegarra M, Flores R, Brenière F, Cardozo L, Dujardin JP 1998. Cryptic speciation in Triatoma sordida (Hemiptera: Reduviidae) from the bolivian Chaco. Trop Med Int Health 3: 364-372.

Panzera F, Hornos S, Pereira J, Cestau R, Canale D, Diotaiuti L, Dujardin JP, Perez R 1997. Genetic variability and geographic differentiation among three species of triatomine bugs (Hemiptera: Reduviidae). Am J Trop Med Hyg 57: 732-739. 
Pietrokovsky S, Bottazi V, Gajate P, Canale D, Wisnivesky-Colli C 1994. Studies on reproductive compatibility between Triatoma sordida and Triatoma guasayana. Mem Inst Oswaldo Cruz 89 (Suppl. I): 379-385.

Schofield CJ 1994. Triatominae: Biology and Control, Eurocommunica Publications, West Sussex, UK, 80 pp.

Thorpe JP, Solé-Cava AM 1994. The use of allozyme electrophoresis in invertebrate systematics. Zool Scripta 23: 3-18.

Usinger RL, Wygodzinsky P, Ryckman RE 1966. The biosystematics of Triatominae. An Rev Entomol 11: 309-330.

Wisnivesky-Colli C, Gürtler RE, Solarz ND, Schweigmann NJ, Pietrokovsky SM, Alberti A, Flo J 1993. Dispersive flight and house invasion by Triatoma guasayana and Triatoma sordida in Argentina. Mem Inst Oswaldo Cruz 88: 27-32.

Wisnivesky-Colli C, Schweigmann NJ, Pietrokovsky S, Bottazi V, Rabinovich JE 1997. Spatial distribution of Triatoma guasayana (Hemiptera: Reduviidae) in hardwood forest biotopes in Santiago de Estero, Argentina. J Med Entomol 34: 102-109. 
Ecogenetics of Triatominae - François Noireau et al. 